\title{
A CASE WITH SYSTEMIC LUPUS ERITHEMATOSUS MIMICKING COVID-19 PNEUMONIA*
}

\author{
COVID-19 PNÖMONISINI TAKLIT EDEN SISTEMIK LUPUS ERITHEMATOSUS VAKASI
}

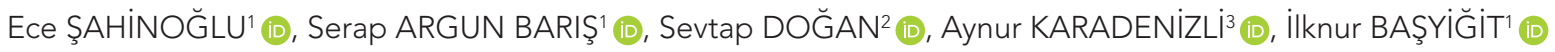 \\ ${ }^{1}$ Kocaeli University, Faculty of Medicine, Department of Pulmonary Disease, Umuttepe, Kocaeli, Turkey \\ ${ }^{2}$ Kocaeli University, Faculty of Medicine, Department of Radiology, Umuttepe, Kocaeli, Turkey \\ ${ }^{3}$ Kocaeli University, Faculty of Medicine, Department of Microbiology, Umuttepe, Kocaeli, Turkey
}

ORCID IDs of the authors: E.Ş. 0000-0002-3422-6433; S.A.B. 0000-0002-4429-9441; S.D. 0000-0002-5862-6730;

A.K. 0000-0002-8267-5284; i.B. 0000-0001-7706-9311

Cite this article as: Sahinoglu E, Argun Baris S, Dogan S, Karadenizli A, Basyigit I. A case with systemic lupus erithematosus mimicking COVID-19 pneumonia. J Ist Faculty Med 2021;84(4):595-8. doi: 10.26650/IUITFD.2021.912861

\begin{abstract}
Coronavirus-19 disease (COVID-19) is a worldwide health emergency which has a high mortality ratio. Diagnosis requires a positive quantitative real-time polymerase chain reaction (qRT-PCR) test however there are radiological findings strongly suggest the diagnosis of COVID-19. Here we reported a 63-yearold woman presented with cough and dyspnea and medical history of lung cancer and systemic lupus erythematosus (SLE). Chest computed tomography demonstrated widespread ground glass opacities in both lung fields that have been reported to be compatible with COVID-19 pneumonia. qRT-PCR test was negative for twice and radiological regression after hydroxychloroquine, azithromycin and piperacillintazobactam was not significant. Considering lung involvement of SLE methylprednisolone was initiated, symptoms and radiological findings improved. The underlying diseases may mimic the COVID-19 infection or the signs and symptoms of the disease may be seen together with COVID-19.
\end{abstract}

Keywords: COVID-19, pneumonia, systemic lupus erythematosus, differential diagnosis

\section{ÖZET}

Koronavirus-19 hastalığı (COVID-19), dünya genelinde yüksek mortalite oranına sahip sağlık acil durumudur. Radyolojik bulguların COVID-19 ile uyumlu olmasının yanında, kantitatif gerçek zamanlı polimeraz zincir reaksiyonu (qRT-PCR) testinin pozitifliği tanı için gereklidir. Bu çalışmada, 63 yaşında akciğer kanseri ve sistemik lupus eritematozus (SLE) öyküsü olan, öksürük ve nefes darlığı ile başvuran bir kadın hasta sunuldu. Toraks tomografisinde; COVID-19 pnömonisi ile uyumlu olan her iki akciğer alanlarında da yaygın buzlu cam dansiteleri saptandı. İki kez bakılan qRT-PCR testi negatif olarak raporland. Hidroksiklorokin, azitromisin ve piperasilin-tazobaktam tedavisi sonrası anlamlı bir radyolojik düzelme görülemedi. SLE'nin akciğer tutulumu olabileceği düşünülerek metilprednizolon başlanan hastanın semptomlarında ve radyolojik bulgularında iyileşme izlendi. Altta yatan hastalıklar COVID-19 enfeksiyonunu taklit edebilir veya hastalığın belirti ve bulguları COVID-19 ile birlikte görülebilir.

Anahtar Kelimeler: COVID-19, pnömoni, sistemik lupus eritematozus, ayırıcı tanı

*This case report was presented as an electronic poster at $50^{\text {th }}$ Anniversary National Congress of Turkish Respiratory Society in October 2020.

Corresponding author/iletişim kurulacak yazar: eceyetiskin@hotmail.com

Submitted/Başvuru: 11.04.2021 • Revision Requested/Revizyon Talebi: 26.07.2021 •

Last Revision Received/Son Revizyon: 26.07.2021 • Accepted/Kabul: 30.07.2021 • Published Online/Online Yayın: 17.09.2021 


\section{INTRODUCTION}

Coronavirus-19 disease (COVID-19) was detected in Wuhan, China in December 2019 (1). Severe acute respiratory syndrome coronavirus-2 (SARS-Cov-2) which is an RNA virus is responsible for the condition (2). COVID-19 pneumonia particularly affects the lower lobes of the lung. Ground glass opacities (GGO) involving multiple lobes of the lung can be generally detected (3). The aim of this case report is to emphasize the importance of differential diagnosis in patients with underlying disease in pandemic era so as not to miss the lung involvement of the primary disease.

\section{CASE}

A 63-year-old woman was admitted to our inpatient clinic for cough and shortness of breath. She had a medical history of systemic lupus erythematosus for 11 years and left upper lobectomy for squamous cell lung cancer seven months ago. She was given carboplatin and paclitaxel chemotherapy regimen and had ongoing radiotherapy for bone metastasis on the second rib. She had a 40 pack year history of smoking. On admission, her oxygen saturation on room air was measured as 89 percent by pulse oximeter. Arterial blood sample was obtained and there was neither acidosis nor hypercapnia. It showed that partial pressure of oxygen $(\mathrm{PaO} 2)$ was $54 \mathrm{mmHg}$ which was consistent with hypoxemia and hypoxemic respiratory failure. Through administration of the high flow nasal cannula oxygen, oxygen saturation hardly reached 95 percent.

Chest X-ray showed reticulonodular opacities in both lung fields, elevated left hemidiaphragm due to left upper lobectomy (Figure 1). Previous radiological images of the patient demonstrated that there was mild lung involve-

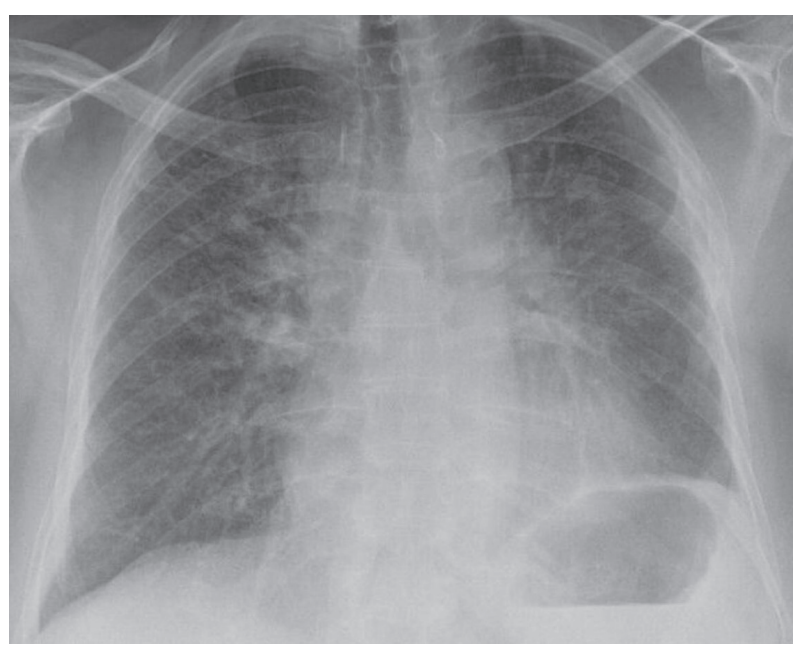

Figure 1: Chest radiography; reticulonodular opacities in both lung fields, elevated left hemidiaphragm ment from lupus. Chest computed tomography (chest CT) was performed which revealed widespread ground glass opacities in both lung fields that have been reported to be consistent with COVID-19 pneumonia due to the pandemic (Figure 2a, 2b). Blood work showed normal white blood cell count and low lymphocyte count $\left(0,3 \times 10^{3} / \mathrm{mL}\right)$. The level of d-dimer was higher than 20 microgram $/ \mathrm{mL}$. Erythrocyte sedimentation rate (ESR) was slightly elevated. Lactate dehydrogenase enzyme level was extremely high at $923 \mathrm{U} / \mathrm{L}$. C-reactive protein level was $81 \mathrm{mg} / \mathrm{dl}$ (laboratory upper limit is lower than $5 \mathrm{mg} / \mathrm{dl}$ ).

Both laboratory findings and radiological evidence were compatible with COVID-19 pneumonia. Combined nasopharyngeal and oropharyngeal swab sample was taken to evaluate COVID-19 by GRT-PCR on 2 different occasions-subsequently on admission and after 24 hours. However, at the beginning of the pandemic, we could

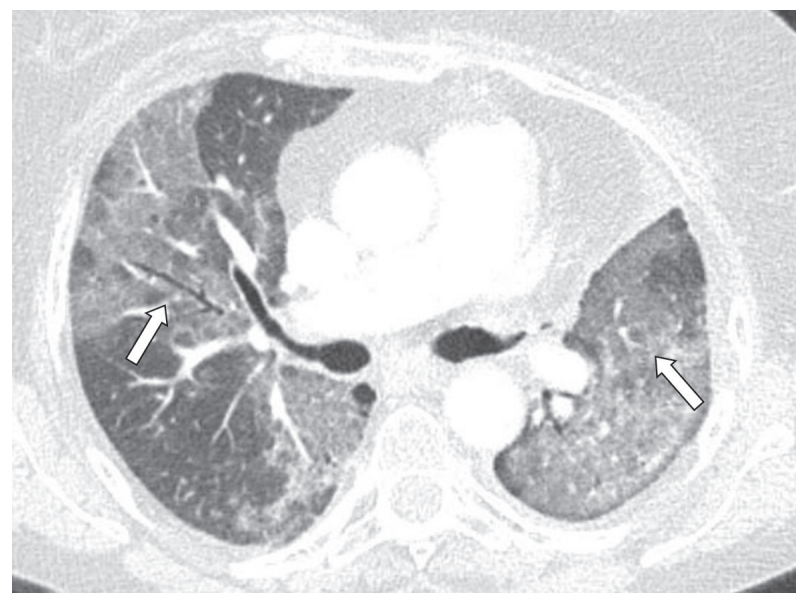

Figure 2a: Contrast enhanced tomography: diffuse ground glass opacities in both lung fields

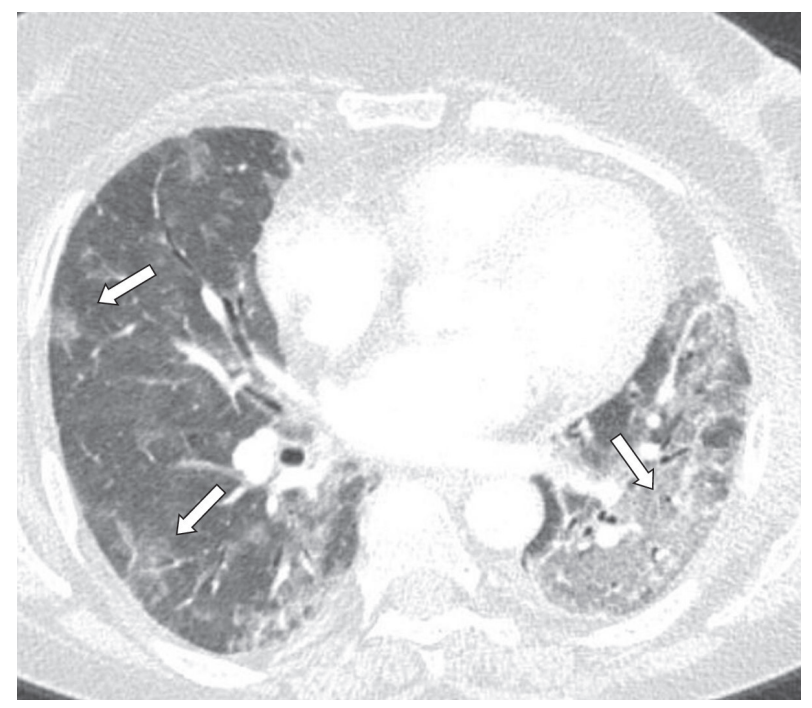

Figure $\mathbf{2 b}$ : Both diffuse and patchy ground glass opacities 
only have the GRT-PCR results almost 24-36 hours later because of the limited number of PCR laboratories. The chest CT indicated the GGO might be related to viral pneumonia, other interstitial pneumonia types and lung involvement of lupus. Until the PCR results were known hydroxychloroquine, azithromycin, piperacillin-tazobactam and low molecular weight heparin was started. The COVID-19 gRT-PCR test results were both negative.

Although the above mentioned therapy was completed, our patient still needed oxygen supply through the high flow nasal cannula (flow: $60 \mathrm{~L} / \mathrm{dk}$, fraction of inspired oxygen: $50 \%$ ) and also there was no significant radiological improvement. Dyspnea was worsening in spite of improving acute phase reactants. The patient was evaluated again after a 5-day-therapy considering history of her systemic lupus erythematosus (SLE) to ascertain whether the radiological findings could be related to SLE. According to this reassessment methylprednisolone $40 \mathrm{mg}$ intravenously was started. She responded to the prednisolone therapy dramatically. She declared her dyspnea had improved after 3-day-prednisolone therapy. Afterwards she was discharged with a recommendation to continue prednisolone for a while until the next outpatient clinic check-up. Due to the fact that Oxygen requirement diminished gradually and oxygen saturation on room air was 92 percent through pulse oximeter, long-term oxygen therapy was not planned. Immunoglobulin $\mathrm{M}$ and $\mathrm{G}$ type antibodies against COVID-19 were also evaluated and were found negative on the 7th and 21st days of admission. Radiological findings disappeared after 6-month-prednisolon therapy (Figure 3). According to these findings and response to anti-inflammatory therapy patient was accepted as lung involvement due to SLE.

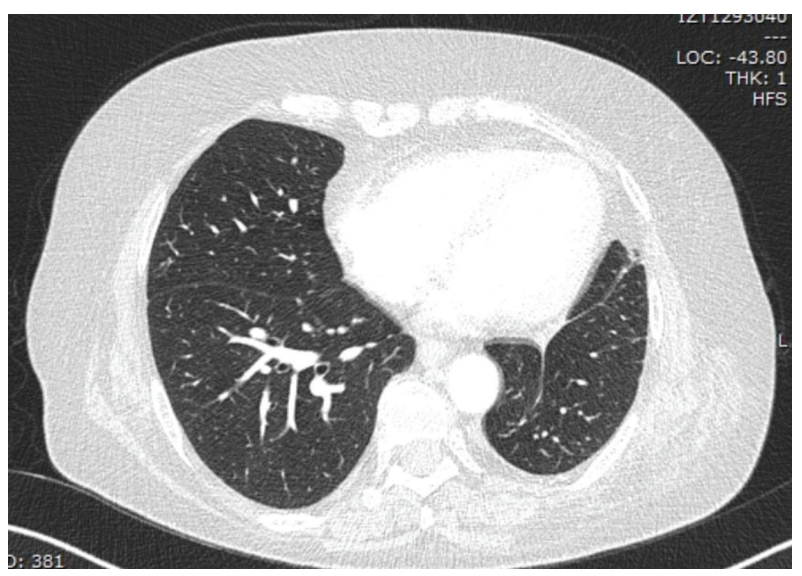

Figure 3: After 6-month-corticosteroid therapy; resolution of ground glass opacities

\section{DISCUSSION}

The coronavirus-19 disease was first identified in Wuhan, China at the end of 2019 (1). The causative agent of the disease is a RNA virus, called severe acute respiratory syndrome coronavirus-2 (SARS-Cov-2) (2). Typical chest computed tomography features of COVID-19 pneumonia are ground glass opacities (GGO), involving multiple lobes of the lung and notably the lower lobes (3). Pan et al. reported GGO in $85.7 \%$ of 63 COVID-19 RT-PCR test positive patients (4). Salehi et al. reported a systematic review and demonstrated that GGO was the most common CT findings of COVID-19 with $88.0 \%$ of 919 COVID-19 patients (5). In our case, due to the COVID-19 pandemic, we initially researched any clues of coronavirus infection, keeping in mind the pulmonary involvement from the underlying SLE. Since, both lupus pneumonitis and COVID-19 pneumonia could be characterized by fever, dyspnea, cough and hypoxia, it was a challenge to make differential diagnosis (6).

SLE is an autoimmune, multisystemic, chronic disease which can affect the lungs as well (7-11). Although pleurisy is common, incidence of interstitial pneumonia is lower in SLE. Lian et al. reported that ground glass opacities are the commonest pattern among interstitial involvement patterns of SLE on chest computed tomography (9).

Our patient was diagnosed as SLE 11 years ago. During the diagnosis, the patient had a positive anti-nuclear antibody (ANA) result (1/160, homogenous pattern) and anti-dsDNA antibodies were also positive. The complete blood count revealed mild lymphopenia (1000 cells $/ \mathrm{ml}$ ). At the time of diagnosis, on physical examination, the patient was afebrile with malar rash.

In our case it was a challenging predicament whether it was COVID-19 pneumonia or lung involvement from lupus. As it is well known, there is no particular treatment for interstitial pneumonia of SLE. Corticosteroids and other immunosuppressive agents are used for both SLE itself and lung complication $(12,13)$. Although the COVID-19 real time PCR was negative twice, hydroxychloroquine, azithromycin and piperacillin-tazobactam therapy were initiated. Because both ongoing chemotherapy and radiotherapy make the host more vulnerable to any kinds of infectious disease and causing elevated acute phase reactants, treatment was completed. Clinical or radiological responses were not good enough after the treatment and the patient still had dyspnea and cough. That made us re-evaluate the patient as pulmonary complication of SLE, and corticosteroid (CS) therapy was started. Through the CS therapy, the dyspnea, cough and clinical condition improved. The radiological findings significantly disappeared (Figure 3). Meanwhile Immunoglobulin $\mathrm{M}$ and $\mathrm{G}$ antibodies against COVID-19 became negative as well. Improvements of symptoms and radiological features after CS therapy dictates that progression of underlying SLE disease should also be considered even during pandemic. 
Differential diagnosis of COVID-19 and other diseases is essential. Chen et al. reported a pulmonary contusion case having trauma history and GGO on chest CT resembling COVID-19 pneumonia that was spontaneously alleviated (14). It should be noted that COVID-19 may concomitantly superimpose on an underlying condition. Bekci et al. reported a 7-year-old boy with a history of trauma having both COVID-19 pneumonia with positive qRT-PCR and pulmonary contusion (15).

The aim of this case is to emphasize the differential diagnosis of COVID-19 pneumonia. In the pandemic period; it is reasonable to consider the diagnosis of COVID-19 in all patients whose clinical and/or radiological findings suggested disease. However, alternative diagnoses should also be kept in mind especially in patients with underlying diseases. Additionally, it should not be forgotten that COVID-19 and other infectious or non-infectious disease with pulmonary involvement may coexist.

\section{CONCLUSION}

Ground glass opacities on chest CT is a significant dilem$m a$ in the COVID-19 era. Real time PCR and laboratory findings can be helpful for differential diagnosis. It should be kept in mind that pulmonary involvement of any systemic condition, infectious diseases other than COVID-19 and trauma may mimic radiological findings of COVID-19 or may co-exist with COVID-19.

Informed Consent: Written consent was obtained from the participants.

Peer Review: Externally peer-reviewed.

Author Contributions: Conception/Design of Study- E.Ş., I.B., S.A.B.; Data Acquisition- E.Ş., S.D.; Data Analysis/Interpretation- A.K., I.B.; Drafting Manuscript- E.Ş., A.K.; Critical Revision of ManuscriptI.B., S.D., S.A.B.; Approval and Accountability- S.A.B., S.D., A.K., I.B.

Conflict of Interest: Authors declared no conflict of interest.

Financial Disclosure: Authors declared no financial support.

Bilgilendirilmiş Onam: Katılımcılardan bilgilendirilmiş onam alınmıştır.

Hakem Değerlendirmesi: Dış bağımsız.

Yazar Katkıları: Çalışma Konsepti/Tasarım- E.Ş., i.B., S.A.B.; Veri Toplama- E.S.., S.D.; Veri Analizi/Yorumlama- A.K., I.B; Yazı Taslağı- E.Ş., A.K.; Içeriğin Eleştirel İncelemesi- I.B.,S.D., S.A.B.; Son Onay ve Sorumluluk- S.A.B.,S.D., A.K., I.B.

Çıkar Çatışması: Yazarlar çıkar çatışması beyan etmemişlerdir.

Finansal Destek: Yazarlar finansal destek beyan etmemişlerdir.

\section{REFERENCES}

1. Lu H, Stratton CW, Tang YW. Outbreak of pneumonia of unknown etiology in Wuhan, China: The mystery and the miracle. J Med Virol 2020;92(4):401-2. [CrossRef]

2. Coronaviridae Study Group of the International Committee on Taxonomy of Viruses. The species Severe acute respiratory syndrome-related coronavirus: classifying 2019-nCoV and naming it SARS-CoV-2. Nat Microbiol 2020;5(4):536-44. [CrossRef]

3. Wang Y, Dong C, Hu Y, Li C, Ren Q, Zhang X, et al. Temporal changes of CT findings in 90 patients with COVID-19 pneumonia: a longitudinal study. Radiology 2020;296(2):E55-E64. [CrossRef]

4. Pan Y, Guan H, Zhou S, Wang Y, Li Q, Zhu T, et al. Initial CT findings and temporal changes in patients with the novel coronavirus pneumonia (2019-nCoV): a study of 63 patients in Wuhan, China. Eur Radiol 2020;30(6):3306-9. [CrossRef]

5. Salehi S, Abedi A, Balakrishnan S, Gholamrezanezhad A. Coronavirus disease 2019 (COVID-19): A systematic review of imaging findings in 919 patients. AJR Am J Roentgenol 2020;215(1):87-93. [CrossRef]

6. Keane MP, Lynch JP. III. Pleuropulmonary manifestations of systemic lupus erythematosus. Thorax 2000;55(02):159-66. [CrossRef]

7. Mathai SC, Danoff SK. Management of interstitial lung disease associated with connective tissue disease. BMJ 2016;352:h6819. [CrossRef]

8. Pego-Reigosa JM, Medeiros DA, Isenberg DA. Respiratory manifestations of systemic lupus erythematosus: old and new concepts. Best Pract Res Clin Rheumatol 2009;23(4):469-80. [CrossRef]

9. Lian F, Zhou J, Wang Y, Cui W, Chen D, Li H, et al. Clinical features and independent predictors of interstitial lung disease in systemic lupus erythematosus. Int J Clin Exp Med 2016;9(2):4233-42

10. Fidler L, Keen KJ, Touma Z, Mittoo S. Impact of pulmonary disease on patient-reported outcomes and patient performed functional testing in systemic lupus erythematosus. Lupus 2016.25:1004-11. [CrossRef]

11. Fenlon HM, Doran M, Sant SM, Breatnach E. Highresolution chest $\mathrm{CT}$ in systemic lupus erythematosus. AJR Am J Roentgenol 1996;166:301-7. [CrossRef]

12. Bertsias G, loannidis JP, Boletis J, Bombardieri S, Cervera $R$, Dostal C, et al. EULAR recommendations for the management of systemic lupus erythematosus. Report of a Task Force of the EULAR Standing Committee for International Clinical Studies Including Therapeutics. Ann Rheum Dis 2008;67:195-205. [CrossRef]

13. van Vollenhoven RF, Mosca M, Bertsias G, Isenberg D, Kuhn A, Lerstrøm K, et al. Treat-to-target in systemic lupus erythematosus: recommendations from an international task force. Ann Rheum Dis 2014;73:958-67. [CrossRef]

14. Chen LR, Chen ZX, Liu YC, Peng L, Zhang Y, Xu Q, et al. Pulmonary contusion mimicking COVID-19: A case report. World J Clin Cases 2020;8(8):1554-60. [CrossRef]

15. Bekci T, Aslan S, Cakir IM. COVID- 19 pneumonia misdiagnosed as pulmonary contusion in a child. $\mathrm{Br} \mathrm{J}$ Hosp Med 2020;81(5):1. [CrossRef] 